\title{
WATER MICROELEMENT COMPOSITION INFLUENCE ON THE EFFICIENCY OF THE MILK POWDER DISSOLUTION PROCESS
}

\author{
Svetlana N. Turovskaya ${ }^{1}{ }^{\text {; }}$ Andrey N. Petrov ${ }^{2}$, Iskra A. Radaeva ${ }^{1}$, Elena E. Illarionova ${ }^{1}$, \\ Vladislav K. Semipyatniy ${ }^{3}$, Anastasia E. Ryabova ${ }^{3}$ \\ ${ }^{1}$ All-Russian Research Institute of Dairy Industry, Moscow, Russia \\ ${ }^{2}$ All-Russian Scientific Research Institute of Technology of Preservation - Branch \\ of the V.M. Gorbatov Federal Research Center for Food Systems of RAS, Vidnoe, Russia \\ ${ }^{3}$ All-Russian Scientific Research Institute of the Brewing, Non-Alcoholic and Wine Industry - Branch \\ of the V.M. Gorbatov Federal Research Center for Food Systems of RAS, Moscow, Russia
}

KEY WORDS:

water microelement composition milk powder, water treatment methods, dissolution, quality and safety

\begin{abstract}
:
Drinking water is important in food production. Its indicators have a direct impact on the quality and safety of finished products, the technological equipment efficiency, etc. In most food technologies, involving the use of milk powder, a priori use the process of its preliminary hydration, that is, dissolution or recovery. In this connection, there is a need to generalize the existing theoretical and practical foundations of this process and find ways to further improve them. Analysis of scientific and technical material in this area showed, that a number of scientists proposed various descriptions not only of individual stages, but also of the dissolution process as a whole, and its determining factors were identified, mathematical models were built, making it possible to determine critical areas depending on from the properties of the raw materials and the process, data were obtained on the parameters of the system during the dissolution of dry dairy products.

In the article presents the sanitary and hygienic, physicochemical and organoleptic require-ments for drinking water by Russian legislation, international organizations and national standards of a number of countries.

Presented a review of widely used and promising water treatment methods.

Analyzed data, describing the effect of the microelement water composition on the efficiency of milk powder dissolving process. It is shown, that decrease of water total hardness and dry substances of mass fraction adjustment in the reconstituted milk have a positive effect on the dissolution process efficiency.

Was noted the relevance of further researches on the directional formation of water trace ele-ment composition for increasing the efficiency of milk powder dissolving and to obtain re-constituted dairy systems, used in the production of various food products of predicted quality and safety.
\end{abstract}

\section{Introduction}

Drinking water is used in all sectors of the food industry, both as a raw material component and to ensure the technological equipment operation, sanitary measures, etc. In this regard, its quality and safety are subject to special requirements, officially regulated by relevant rules and norms. Drinking water should be harmless, including microbiological characteristics, have high organoleptic and standards-compliant physicochemical indicators. In general, from its quality and safety, indirectly depend sensory, physical, chemical and microbio-logical indicators of food products. $[1,2,3,4,5,6]$.

The food industry receives water from the drinking water supply system and/or from artesian wells. Due to the particular technology of obtaining food products, not only every branch of the food industry as a whole, but often individual enterprises develop their own additional requirements for water. All this fully applies to plants, producing dairy products $[7,8,9]$. It is known, that the majority of dairy technologies imply the use of dry dairy products after their preliminary dissolution process, which in the practice of the dairy industry, is defined by the term "reconstitution" [10,11].

It should be noted, that in 2016-2018 the total volume of the Russian dry milk products market in real terms was 290310 thousand tons, a large share of which was instant skimmed milk powder (more than $60 \%$ ). Imports exceeded the volumes of Russian production by $30-50 \%$, the overwhelming part of which (80-90 \%) came from the Republic of Belarus [12,13]. The actual volumes of the reconstituted product approximately exceed the amount of processed milk powder by an order of magnitude [7].

The reconstitution process effectiveness depends on many factors, namely the milk powder functional and technological properties, the water quality, the process conditions, the used equipment, etc. If the properties of dry products in this aspect are sufficiently studied $[3,7,14,15,16,17,18,19,20,21,22,23,24]$, and the choice of technological equipment and parameters a priori implies a factor of excessive exposure [25,26,27,28,29,30,31], the water effects on the process efficiency, until recently, is presented rather fragmented. In recent years were proposed modern models of the dissolution process, taking into account water properties [32,33,34,35,36,37,38,39]. Was researched the effectiveness of traditional (reverse-osmotic, ionexchange), as well as a number of poorly studied methods of water treatment $[40,41]$. Results are presented on the effects of hardness, $\mathrm{pH}$, and other water indicators on the quantitative and qualitative yield $[26,42,43,44,45,46]$. In this case, a priori, special attention should be paid to the study of the water microelement composition influence, as well as the determination of the dynamics and changes in the nature of dissolution in dependence on temperature and time parameters and the fat content of milk powder. The stated problem is relevant, because it is aimed at improving the technology of reconstituting dry dairy products, reducing losses and improving the quality of finished products.

\section{Main part}

A sufficient amount of works has been devoted to the study of the theoretical and practical aspects of reconstituting process of multicomponent powdered products. In particular, the work of the following scientists should be noted: N.N.Lipatova (Snr.), V.D.Kharitonova, K.I.Tarasova, Yu.I.Filatova, G.A.Akselrud, A.B.Zdanovsky, A.N.Planovsky, A.N.Petrova, A.G.Galstyan and others. At the same time, it was revealed that the reconstitution 
process was considered in most of the works from the standpoint of studying the functional and technological properties of dry dairy products, the development of apparatuses and technological processes [26,27,42,47,48]. Much less attention was paid to studying the properties of the complete system and, in particular, water as a solvent. According to this direction, should be highlighted the works of K.I.Tarasova and A.G.Galstyan, confirming that water composition and properties have a significant effect on the efficiency of the reconstitution process of dry milk systems $[8,25,32,40,49,50,51,52,53]$.

As a result of the use of various products [7,26,27,42,47,48], in finished products were obtained organoleptic and physicochemical properties which are necessary for the organism. The term "reconstitution" can be replaced by the term "dissolution": a heterogeneous chemical reaction, a flow between solids and a liquid, and transitional substances accompanying it into solution. Physical mass transfers of relatively pure chemicals during dissolution, the kinetics of the process, as well as mathematical models of the dissolution of researchers is quite comprehensive. As for polycomponent systems, the process may proceed differently. The current state of the dissolution theory doesn't allow to get a complete description of the process. This refers to the reconstitution of dry dairy products. This means, that reconstitution and search of the ways to further improve them $[25,32,54]$.

The main requirement for dry dairy products, is that after reconstitution they must have the properties inherent to them before drying. The reconstitution process should ensure the complete product particles dissolution and the rapid transition of all milk components into solution [7,26,27,42,47,48,52,53].

Analysis of the scientific and technical material in this area showed, that a number of scientists attempted to study the process of dissolving dry dairy products in water, namely, on the basis of theoretical works and experimental studies, various descriptions were offered of either the process as a whole or its individual stages $[25,52,55,56,57,58,59]$.

In the work [47], a model of one of the stages of the dissolution process was considered in detail: impregnation of the product layer, depending on its properties. When describing a model system, consisting of a tube, filled with a product layer, wetted by capillary pressure forces, the author obtained a criterial equation, describing the ability of dry dairy products to wetting, and also substantiated, that the particle size and hydrophilic properties of their surface have a decisive influence on the ability of milk powder to wet. This attempt to apply the similarity method was limited to the consideration of the model for one of the dissolution process stages.

An analysis of the process as a whole was described in [48]. The author, to optimize the operation of the experimental stand and apparatus for dissolving milk powder, combined the analysis of experimental data with the theoretical foundations of mass transfer processes, which made it possible to propose optimal technological parameters for the process of milk powder dissolving in horizontal flow-type machines, such as mixture temperature, mixing time, and peripheral speed rotation of the mixer, solids concentration. It was also found, that the effectiveness of the milk powder dissolving process is mainly influenced not by the mixing duration, but by its intensity.

The essence of the dissolution process according to [42] interaction of the dry dairy products constituent parts with water and includes several steps: dissolving milk sugar (lactose) and minerals in water, the distribution of fat and protein fractions in the dispersion medium (dispersed phase hydration), the release from the product of excess air. The high system dispersion, resulting from the dissolution of these components, creates the preconditions for the intensive hydration of the dispersed phase due to the significant contact surface of the dispersed phase with water. Extraction from the product particles of excess air occurs during the entire of dry dairy products reconstitution process. The rate of gas evolution has an effect on the flow rate of the other reconstitution stages. When gases are released from the products, capillaries and pores of the dissolving particles are released and the contact surface is increased. It should be noted, that the saturation of the aqueous phase with air occurs in many cases even due to the intensive mixing of the product being reconstituted. With regard to milk powder, the reconstitution process can be considered complete when the physicochemical properties of reconstituted milk correspond to those of natural milk, and the organoleptic indicators of reconstituted milk are no worse than the organoleptic indices of drinking pasteurized milk. At the same time, such indicators as density, viscosity, dispersion, amount of bound water, characterize the completeness of the process under the condition of equal quantitative content and ratio of components in the dry and reconstituted product [26].

Also, in the study of dry milk products dissolution in water, proposed to conventionally divide the process into two stages: the first is proceeding at a relatively high rate and limited by the ability of milk powder to be quickly moistened with water; the second is slower, significant effect on which has a high solution concentration [27].

The reconstitutability of dry dairy products depends on the dissolution completeness and rate.

Dissolution completeness is the amount of product solids that has passed into solution and not precipitated from it, i.e. in equilibrium. It allows evaluating dry product components transition into solution regardless of time and is predetermined mainly by the structure of single particles and properties of the milk constituent parts. The main standardized indicator characterizing the completeness of dry dairy products dissolution in the Russian Federation is the solubility index, which is the volume of sediment (insoluble residue) obtained after reconstituting and centrifuging of dry dairy products under certain temperature and time conditions. The solubility index is expressed in cubic centimeters of raw sludge, which corresponds to the percentage of dry dairy products dry insoluble residue $[27,42,60,61,62]$.

The dissolution rate is the rapidity of dry dairy products constituent parts transition to the solution. To estimate this indicator, the method of determining the relative dissolution rate is used, which characterizes the percentage of dry product that has gone into solution during short-term mechanical mixing of the dry product sample in a given amount of water with a certain temperature $[27,42]$.

Currently, the problem under study has found its further development. Thus, in a number of works $[1,8,32,33,34,35,63,64]$, proposed comprehensive solutions of solving the problem from the standpoint of increasing the dissolution efficiency and reducing losses by creating a model that applies to entire reconstitution process. The authors analyzed, systematized and functionally related factors that have already been identified, which determine the kinetics of the process, built a mathematical model that makes it possible to determine critical areas depending on the properties of raw materials (dry dairy products, drinking water) and the process, obtained data on the system parameters (temperature, concentration, duration) when dissolving dry dairy products in conditions as close to static as possible. It has been established, that among the production losses it is most expedient to rationalize the energy costs of the hydration process. Algorithms have also been created and special computer programs have been developed 
for calculating the heat balance, energy consumption, ascent rate, flow regimes, time of particles settling in solutions with varying medium parameters [65,66,67,68,69].

Thus, the determining factors of the recovery process are:

- of dry dairy products properties (size, shape, porosity, wettability, penetrability, submersibility, dry particles dispersibility; density, grain size, dry produc cohesiont; composition and physical state of the components);

- technological parameters (intensity, duration and exposure method, process temperature);

- water properties (salt content, active acidity, mineralization degree, etc.).

Currently, in the Russian Federation requirements for drinking water are standardized by SanPiN 2.1.4.1074-01 "Drinking Water. Hygienic Requirements for Water Quality of Cen-tralized Drinking Water Supply Systems. Quality Control. Hygienic Requirements to Ensure the Safety of Hot Water Systems. Table 1 shows the microbiological, parasitological, physi-cochemical, and organoleptic requirements, imposed to drinking water by Russian legislation, international organizations, and the national standards of a number of countries [7,69,70,71].

Table 1.

Drinking Water Quality Indicators

\begin{tabular}{|c|c|c|c|c|c|}
\hline Indicator & RF & WHO & EU & China & USA \\
\hline \multicolumn{6}{|c|}{ Generalized Indicators } \\
\hline Hydrogen indicator & $6.0-9.0$ & $6.5-8.0$ & $6.5-9.5$ & $6.5-8.5$ & $6.5-8.5$ \\
\hline Total mineralization & $1000 \mathrm{mg} / \mathrm{l}$ & $600 \mathrm{mg} / \mathrm{l}$ & ----- & $1000 \mathrm{mg} / \mathrm{l}$ & $500 \mathrm{mg} / \mathrm{l}$ \\
\hline Total stiffness & 7 mg-eq/1 & $100 \mathrm{mg} / \mathrm{l}(\mathrm{Ca} 2+)$ & ----- & $450 \mathrm{mg} / \mathrm{l}(\mathrm{CaCO} 3)$ & ------ \\
\hline $\begin{array}{l}\text { Permanganate } \\
\text { oxidation }\end{array}$ & $5 \mathrm{mg} / \mathrm{l}$ & ----- & $5 \mathrm{mg} / \mathrm{l}$ & $3 \mathrm{mg} / \mathrm{l}$ & $-\cdots$ \\
\hline $\begin{array}{l}\text { Oil products, } \\
\text { total }\end{array}$ & $0.1 \mathrm{mg} / \mathrm{l}$ & ----- & ------ & ----- & ----- \\
\hline $\begin{array}{l}\text { Superficially active } \\
\text { substance. (SAS), } \\
\text { Anionic surfactants }\end{array}$ & $0.5 \mathrm{mg} / \mathrm{l}$ & ----- & ------ & ----- & $0.5 \mathrm{mg} / \mathrm{l}$ \\
\hline Phenol Index & $0.25 \mathrm{mg} / \mathrm{l}$ & ----- & ------ & ----- & ----- \\
\hline \multicolumn{6}{|c|}{ Microbiological and Parasitological Indicators } \\
\hline $\begin{array}{c}\text { Thermotolerant } \\
\text { coliform bac-teria } \\
\text { (E.coli) }\end{array}$ & 0/100 ml & 0/100 ml & 0/100 ml & 0/100 ml & ----- \\
\hline $\begin{array}{l}\text { Common coliform } \\
\text { bacteria }\end{array}$ & 0/100 ml & ----- & 0/100 ml & $0 / 100$ & $\begin{array}{l}\leqslant 5 \% \text { samples per } \\
\text { month }\end{array}$ \\
\hline Total microbial count & $\leqslant 50 \mathrm{CFU} / \mathrm{ml}$ & ----- & ------ & ----- & ------ \\
\hline Coliphages & $0 / 100 \mathrm{ml}$ & ----- & $0 / 100 \mathrm{ml}$ & ------ & ------ \\
\hline Lamblia cysts & $0 / 501$ & ----- & ----- & $<1 / 101$ & $\begin{array}{l}99.9 \% \text { delete/ } \\
\text { inactivation }\end{array}$ \\
\hline \multicolumn{6}{|c|}{ Organoleptic Indicators } \\
\hline Odor & 2 points & ----- & $\begin{array}{l}\text { Acceptable, without } \\
\text { anomalous changes }\end{array}$ & $\begin{array}{l}\text { Without anomalous } \\
\text { changes }\end{array}$ & $\begin{array}{l}3 \text { odour } \\
\text { threshold } \\
\text { number }\end{array}$ \\
\hline Smack & 2 points & ------ & $\begin{array}{l}\text { Acceptable, without } \\
\text { anomalous changes }\end{array}$ & $\begin{array}{l}\text { Without anomalous } \\
\text { changes }\end{array}$ & ----- \\
\hline Chromaticity & $\leqslant 20$ degrees & $\leqslant 15 \mathrm{u}$. & $\begin{array}{l}\text { Without anomalous } \\
\text { changes }\end{array}$ & $\leqslant 15 \mathrm{u}$. & $\leqslant 15 \mathrm{u}$. \\
\hline Turbidity & $\leqslant 2.6 \mathrm{FTU}^{*}$ & $\leqslant 5 \mathrm{NTU}^{* *}$ & $\begin{array}{l}\leqslant 1 \text { NTU (when clean- } \\
\text { ing water from surface } \\
\text { sources) }\end{array}$ & $\leqslant 1 \mathrm{NTU}$ & $\leqslant 5 \mathrm{NTU}$ \\
\hline
\end{tabular}

\footnotetext{
*FTU - Formazin Turbidity Units
}

** NTU - Nephelometric Turbidity Unit

«-----» - the indicator is not standardized

In addition to the indicators given in Table 1 , the requirements for the content of inorganic and organic chemical substances in water, reagents used for water treatment, and radiological standards are subject to state regulation. The number of indicators normalized in drinking water by international organizations and legislation of different countries differs markedly. Currently, a total of 82 indicators of drinking water quality are considered as priority in the territory of the Russian Federation. WHO recommends 85 indicators for regulation, 44-48 indicators in EU countries, 79 in the USA, 89 in China. Despite differences in regulatory bases, seven general groups of indicators can be distinguished, including 53 standard values:

- microbiological (E. coli, coliform bacteria);

- physicochemical (pH, total mineralization);

- organoleptic (turbidity, chromaticity, odor, taste);
- inorganic substances (aluminum, barium, cadmium, arsenic, nitrates, nitrites, mercury, plumbum, selenium, antimony, fluorides, chromium, cyanides, iron, manganese, copper, boron, sodium, sulfates, nickel, ammonia, chlorides, zinc);

- organic compounds (acrylamide, benzene, benz(a)pyrene, vinyl chloride, 1,2- and 1,4-dichlorobenzenes, dichloromethane, 1,2-dichloroethane, di(2-ethylhexyl)phthalate, xylenes, pentachlorophenol, tetrachloroethylene and trichloroethylene, toluene, carbon tetrachloride, epichlorohydrin);

- water disinfection products (bromates, chlorites, trihalomethanes, 2,4,6-trichlorophenol);

- radiological indicators (total alpha activity and total beta activity).

It should be noted, that Russia is ahead of the world community in the development of the regulatory framework 
for the regulation of drinking water quality. In addition to the priorities, there are still 713 additional regulatory indicators, as well as more than 1,800 standards for the content of substances in the cultural and domestic and household water use. In addition, for the first time in the world practice in the Russian Federation, the criterion of physiological usefulness of bottled drinking water and a number of norms of the minimum necessary amount of individual biogenic elements in it under conditions of deficiency of their intake with food products is scientifically substantiated and implemented [72].

The quality of drinking water used in the production of reconstituted dairy products primarily determines the organoleptic, chemical, rheological and microbiological indicators of the finished products. At the same time, such indicators as $\mathrm{pH}$, mineralization, hardness, oxidizability, presence of surfactants, phenol index, as well as the number of various inorganic substances, the excess of which are higher than the established ones, are absolutely unacceptable. However, it should be noted that the complete absence or nonsignificant mass fraction of mineral substances in drinking water is no less serious drawback than their excessive amount. It is well known, that distilled water is considered unsuitable for constant consumption, and the mineral content of certain inorganic substances sometimes impairs the taste of water [42].

One of the main indicators, characterizing the use of drinking water in various industries, is its hardness. In accordance with GOST 31865-2012 "Water. A Unit of Hardness" hardness of water is the combination of properties caused by its alkaline earth element content, mainly calcium ions $\left(\mathrm{Ca}^{2+}\right)$ and magnesium $\left(\mathrm{Mg}^{2+}\right)$, and is expressed in degrees of hardness $\left({ }^{\circ} \mathrm{H}\right)$. The degree of hardness corresponds to the concentration of the alkaline earth element numerically equal to $1 / 2$ of its mole, expressed in mg-eq $/ 1, \mathrm{~mol} / \mathrm{m}^{3}, \mathrm{mg} / \mathrm{dm}^{3}, \mathrm{~g} / \mathrm{m}^{3}$. Normally, this indicator should not exceed $7.0 \mathrm{mg}$-eq/l. However, in some cases (due to natural conditions, as authorized by the sanitary and epidemiological service), the level can be increased to $10.0 \mathrm{mg}$-eq/1.

Traditionally, it is considered sufficient, that the water, used for hydration, meets the rated requirements. However, studies have shown that the solubility of dry dairy products can vary significantly in the range of regulated water parameters. So, with a decrease in water hardness, the solubility of milk powder increases. It is proved that a high level of the mass fraction of calcium and magnesium in water adversely affects on the stability of proteins in reconstituted skimmed milk. Also, the heat resistance of reconstituted dairy products depends on the overall water hardness. Protein coagulation can be prevented by softening the water. The instability of reconstituted milk protein leads to the loss of dry matter [42]. There are recommendations for milk powder reconstitution with softened drinking water with a total hardness of about $0.16 \mathrm{mg}-\mathrm{eq} / \mathrm{l}$, which makes it possible to increase the solubility of milk powder at about $5 \%$ [27].

In the light of the above, a series of experiments were carried out to determine the solubility of dry whole and skimmed milk depending on changes in the total hardness of water, and studies were carried out on the effect of increasing the milk dry solids mass fraction on the effectiveness of the dry dairy products dissolving under different indicators of water hardness. The temperature of the water as a solvent for all samples was within (50.0 \pm 0.5$){ }^{\circ} \mathrm{C}$, which ensured the conditions for the rapid dissolution of the fatty phase of dry milk samples with the simultaneous minimal thermal effect on the protein phase. It is proved, that an increase in the total water hardness in the range from 0 to $10 \mathrm{mg}$-eq/ leads to a decrease in the efficiency of the dry dairy products dissolving process, as well as the heat resistance of the reconstituted compositions. The joint increase in water hardness and the mass fraction of dry substances leads to a sharp decrease in solubility. Was confirmed the absence of a significant effect of the water $\mathrm{pH}$ in the range of 6-9 on the dissolution efficiency of dry dairy products, which is due to the buffer capacity of milk constituents [8,9].

To intensify the dissolution process and increase the thermal stability of dry dairy products at different concentrations of dry substances (in accordance with the technological requirements of various food products production), it is recommended to carry out preliminary preparation of drinking water, choosing a specific scheme based on the implementation of the drinking water chemical composition by replacing and/or removing certain substances; stabilization of microbiological indicators; regulation of physical properties. Properly selected water conditioning helps to improve the quality characteristics of reconstituted dairy products $[8,43,52,53,73,74,75,76]$.

In the food industry, water treatment is carried out by various methods, which can be divided into [49,50,51,75]:

- physical (filtering; temperature, electric, magnetic, acoustic, radio frequency effects; various radiations);

- chemical (precipitation; coagulation; flocculation; oxidation);

- physicochemical (adsorption, physical sorption, chemisorption, ion exchange; electrodialysis).

From the quality and properties of the incoming water, as well as the type and kind of food production depends on the choice of method, and often a combination of methods of drinking water preparation. With regard to the dairy industry, the use of various methods of water treatment solves the problems arising from the interaction of the constituent parts of dry dairy products with many components in the water, namely: sedimentation, thermal instability, increased viscosity or thickening during production and storage, the presence of organoleptic defects, which, in turn, negatively affects on the quality of products further produced from reconstituted milk [40,49].

It should be noted that the microbiological safety of finished products, the technology of which uses reconstituted milk, obtained using the above listed water treatment methods, is ensured by the use of special technological methods of processing milk mixture, such as pas-teurization, ultrapasteurization, sterilization.

Thus, the milk powder dissolution efficiency and the quality of the finished product is formed in accordance with the selected method of water treatment, which in most cases assume the presence of several consecutive elements.

With help of mechanical filters, water is preliminary filtered when it is taken from the main water supply system or well. The filtering element (metal mesh, disc pack, etc.) retains suspended particles in the water (sand, scale, etc.), which makes it possible to regulate in the water only such organoleptic characteristics as turbidity, color, and partly odor. Filters of this design have high productivity and high operational characteristics [50].

From a practical point of view, the data on the effect of temperature water treatment (heat treatment and freezing) on the efficiency of the process of milk powder dissolving are of the greatest interest. It was found that during heat treatment, the maximum effect was observed when using tap water previously heated to a temperature of $95{ }^{\circ} \mathrm{C}$ and cooled to $50{ }^{\circ} \mathrm{C}$. With a decrease in the temperature of preheating of water, the efficiency of the dissolution process decreases, which, according to the authors, is due to a decrease in the total water hardness (to $3.2 \pm 0.2 \mathrm{~mol} / \mathrm{m}^{3}$ ) as a result of hightemperature heating. Based on energy saving considerations, it is suggested to preheat the water before mixing with milk powder to a temperature of $75-85^{\circ} \mathrm{C}$ and cool it to $50{ }^{\circ} \mathrm{C}$. At the same time, the decrease in the solubility index is insignificant 
in comparison with the option of heating water to $95^{\circ} \mathrm{C}$ [50].

The method of separation freezing is one of the most promising and energy efficient, since it eliminates the following steps from the water preparation process: cleaning of mechanical impurities, clarification, removal of active chlorine and dissolved gases. The separating freezing installation consists of two cylinders: in the first one, the process of freezing ice is carried out on the inner surface of the condenser evaporator, in the second - frozen ice is melting. Ice melting is performed by the heat, removed from the frozen water in the first cylinder, which increases the energy efficiency of the installation. Switching cylinders from freezing mode to melting mode is carried out using a special valve. It is proved, that the freezing is energetically advantageous to conduct at temperatures from minus $5{ }^{\circ} \mathrm{C}$ to minus $2{ }^{\circ} \mathrm{C}$. The water, obtained by this method, had 2.5 times reduced total hardness, 8 times reduced dry residue and a reduced content of chlorides and fluorides by 1.7 and 1.9 times respectively, which in turn has a positive effect on the reconstitution process of dry milk. The average solubility index of skimmed milk powder in tap water and water, treated by freezing was $0.35 \pm 0.02$ and $0.1 \pm 0.02$ $\mathrm{cm}^{3}$ of raw sludge, respectively [75].

In recent years, magnetic processing has found wide application in domestic and foreign practice. It contributes to the prevention of scale formation, the intensification of coagulation and crystallization processes, the acceleration of the reagent dissolution, the improvement of the bactericidal action of disinfectants and the water disinfection. The principle of magnetic treatment is that when magnetic field lines pass through water, migrating fine sediment (sludge) is formed not on the heating surface, but in the body of water, from where it is removed. On an industrial scale, devices are used with permanent steel or ferrite barium magnets and electromagnets. In comparison with heat treatment, the method of softening water by magnetic action has several advantages: simplicity, safety, and the almost complete absence of operating costs. Research has shown that magnetized water helps to increase the milk powder solubility by 0.4-0.5\%. However, an increase in the mass fraction of solids in reconstituted milk reduces the milk powder solubility by $0.7-1.1 \%$, while the dissolution efficiency of skimmed milk powder is lower than of whole milk $[41,74,77,78]$.

Acoustic (ultrasonic) treatment is no less promising method of water treatment. Acoustic technology prevents the formation of salts on the surface of heat exchange equipment by ultrasonic excitation of mechanical vibrations in the water column or on the equipment walls, which prevents the crystallization process, partial decontamination, etc. Ultrasonic effect is successfully used to intensify mixing, dispersion, emulsification and other processes. Acoustic generators can be classified into mechanical (the source of ultrasound is the mechanical energy of the fluid (gas) flow) and electromechanical (converting electric power). The advantages of such devices are compactness and low power consumption. The use of preliminary ultrasonic treatment promotes water softening (the destruction of calcium and magnesium salts and precipitation occurs, their concentration decreases), which positively affects on the solubility of dried milk products. Thus, the relative dissolution rate of milk powder in drinking water subjected to ultrasonic treatment lasting from one to five minutes increased from 17.6 to $34.2 \%$, and the averaged results of the solubility index estimate showed a de-crease in this indicator by $37.5 \%$ $50.0 \%[41,49,63,74,77,79,80]$.

Chemical treatment is the most common type of water conditioning. Chlorine compounds, ozone, potassium permanganate, manganese dioxide, manganese zeolite are used as reagents (for disinfecting or oxidizing manganese and iron compounds); salts of iron and aluminum (for coagulation of colloidal suspensions), etc. By combining and sequencing the use of various reagents, you can adjust the composition of water in almost all normalized generalized indicators. The essence of the treatment lies in the fact that oxidation reaction takes place on the surface of the granules of the reagent, which has properties of a catalyst (chemical reaction accelerator), which in turn is a filtering medium $[50,51,74]$.

To reduce the overall water hardness, are also used ion exchange and membrane methods (mainly reverse osmosis). In the course of ion exchange, a successive treatment of water on cation and anion resin filters takes place. When water passes from top to bottom through a column loaded with cation exchanger, all cations present in water are exchanged for hydrogen ions. Then, water enters the upper part of the anion exchange column, where the anions of strong acids are exchanged for hydroxyl ions during regeneration of anion exchanger with caustic soda or ions of the acidic carbonate acid during regeneration with soda ash $[50,51,74]$.

Membrane methods are classified into electromembrane (electrodialysis with ion exchange membranes, electroionization) and baromembrane (reverse osmosis, ultrafiltration, microfiltration). To ensure continuity of the process in the electromembrane apparatus, the driving force is the gradient of the electric potential, and in the bar-membrane ones the hydraulic pressure. The pore size in modern membranes makes it possible to retain almost all substances and microorganisms dissolved in water, thus ensuring drinking water of a given composition and guaranteed high quality. Due to the simplicity and compactness of membrane apparatuses, water treatment in this way is more economical and less energy consuming as compared with other processes [50,51,74].

\section{Conclusion}

Thus, at present, the influence of water composition and properties on the efficiency of the recovery process has been reliably proved. Taking into account the variety of drinking water modern purification methods, further studies on the directed formation of the trace element composition of water are actualized in order to increase the dissolution efficiency. Analysis of the material allows us to predict a mediated increase in the stability of reconstituted dairy systems.

\section{REFERENCES}

1. Titov, S.A. (2011). Hydration in food systems: physical bases and technology of products with desired properties. Author's abstract of the dissertation for the scientific degree of Doctor of Technical Sciences. Voronezh, VGUIT. - 38 p. (in Russian)

2. Boguniewicz-Zablocka, J., Klosok-Bazan, I., Naddeo, V. (2019). Water quality and resource management in the dairy industry. Environmental Science and Pollution Research, 26(2), 1208-1216. DOI: 10.1007/s11356-017-0608-8

3. El-Ziney, M.G., Ammar, A.S., Al-Turki, A.I. (2018). Effectiveness of Groundwater Treat-ment for Drinking Use and Dairy and Food Processing. Advances in Dairy Research, 6(1), 201. DOI: 10.4172/2329888X.1000201.
4. Lerner, K.L., Lerner, B.W. (2005). Basics of water science. Encyclopedia of Water Science, 3, 1-22.

5. Lewicki, P.P. (2004). Water as the determinant of food engineering properties. A review. Journal of Food Engineering, 61(4), 483-495. DOI: 10.1016/S0260-8774(03)00219-X

6. Kasaai, M.R. (2014). Use of Water Properties in Food Technology: A Global View. International Journal of Food Properties, 17(5), 10341054. DOI: 10.1080/10942912.2011.650339.

7. Galstyan,A.G.,Petrov,A.N., Radaeva,I.A., Turovskaya, S.N., Chervetsov, V.V., Illarionova, E.E., Semipyatny, V.K. (2016). Theory and Practice of Dairy Canning. M: The Pub-lishing House "Fedotov D.A.". -181 p. ISBN 978-5-9908238-7-7. (in Russian) 
8. Galstyan, A.G. (2009). Development of Scientific Foundations and Practical Solutions for Improving Technology, Increasing the Quality and Expanding the Range of Canned Milk. The Author's Abstract of the Doctor of Technical Sciences Dissertation. Moscow, V.M. Gorbatov All-Russian Research Institute of Meat Industry, 50 p. (in Russian)

9. Galstyan, A.G., Petrov, A.N., Frolov, G.A., (2008). About restoration of dry dairy products. Storage and processing of farm products, 5, 37-39. (in Russian)

10. Gaiani, C., Schuck, P., Scher, J., Desobry, S., Banon, S. (2007) Dairy powder rehydration: influence of protein state incorporation mode, and agglomeration. Journal of Dairy Science, 90(2), 570-581. DOI: 10.3168/ids.S0022-0302(07)71540-0

11. Gaiani, C., Banon, S., Scher, J., Schuck, P., Hardy, J. (2005). Use of a Turbidity Sensor to Characterize Micellar Casein Powder Rehydration: Influence of Some Technological Effects. Journal of Dairy Science, 88(8), 2700-2706. DOI: 10.3168/jds.S0022-0302(05)72948-9

12. Ministry of Agriculture of the Russian Federation website. [Electronic resource: http://mcx.ru. Access date 01.02.2019] (in Russian)

13. Website of the Federal State Statistics Service [Electronic resource: http://www.gks.ru Access date 01.02.2019] (in Russian)

14. De Ruyck, H. (1991). Avoiding white flecks during the production of instant whole milk powder. Revue De l'Agriculture, 44, 205-215.

15. Sert, D., Mercan, E., Aydemir, S., Civele, M. (2016). Effects of milk somatic cell counts on some physicochemical and functional characteristics of skim and whole milk powders. Journal of Dairy Science, 99(7), 74550, 5254-5264. DOI: 10.3168/jds.2016-10860

16. Peng, F., He, S., Yi, H., Li, Q., Xu, W., Wang, R., Ma, Y. (2018). Physical, textural, and rheological properties of whipped cream affected by milk fat globule membrane protein. International Journal of Food Properties, 21(1), 1190-1202. DOI: 10.1080/10942912.2018.1460755

17. Vyas, H.K., Tong, P.S. (2004). Impact of Source and Level of Calcium Fortification on the Heat Stability of Reconstituted Skim Milk Powder. Journal of Dairy Science, 87(5), 1177-1180. DOI: 10.3168/jds. S0022-0302(04)73266-X

18. Jouppila, K., Roos, Y. H. (1994). Glass transition and crystallization in milk powders. Journal of Dairy Science, 77(10), 2907-2915. DOI: 10.3168/jds.S0022-0302(94)77231-3

19. Kelly, A.L., O’Connell, J.E., Fox, P.F. (2003). Manufacture and properties of milk pow-der. In: Fox PF, McSweeney PLH, editors. Advanced dairy chemistry, vol. 1, proteins. New York: Kluwer Acad/ Plenum Pub. 1027-1054.

20. Kelly, J., Kelly, P.M., Harrington, D. (2002). Influence of processing variables on the physicochemical properties of spray-dried fat-based milk powders. Lait, 82(4), 401-412.

21. Kim, E.H., Chen, X.D., Pearce, D. (2002). Surface characterization of four industrial spray-dried dairy powders in relation to chemical composition, structure and wetting property. Colloid and Surface B: Biointerfaces, 26(3), 197-212. DOI: 10.1016/S0927-7765(01)00334-4

22. Saito, Z. (1985). Particle Structure in Spray-Dried Whole Milk and in Instant Skim Milk Powder as Related to Lactose Crystallization. Food Structure, 4(2), 16.

23. Sikand, V., Tong, P.S., Vink, S., Roy, S. (2016) Physicochemical Properties of Skim Milk Powders Prepared with the Addition of Mineral Chelators. Journal of Dairy Science, 99(6), 4146-4153. DOI: 10.3168/jds.2015-10243

24. Tamime, A.Y., editor. (2009). Dried milk products. Dairy powders and concentrated milk products. Oxford, U.K.: Blackwell Pub. Ltd. 408 p. ISBN 978-1-405-15764-3.

25. Frolov, G.A., Galstyan, A.G., Petrov, A.N. (2008). Theoretical bases of milk powders solving in water. Dairy Industry, 1, 84-85. (in Russian)

26. Tarasov, K.I. (1991). Theoretical and experimental substantiation of technology and tech-nology of dry milk recovery. The Author's Dissertation Abstract of the Doctor of Technical Science. Moscow, V.M. Gorbatov All-Russian Research Institute of Meat Industry - 38 p. (in Russian)

27. Lipatov, N.N., Kharitonov, V.D. (1981). Dried Milk. M: Light and Food Industry.-264 p. (in Russian)

28. Martin, G.J.O., Williams, R.P.W., Dunstan, D.E. (2007). Comparison of casein micelles in raw and reconstituted skim milk. Journal of Dairy Science, 90(10), 4543-4551. DOI:10.3168/jds.2007-0166.

29. Mounir, S., Schuck, P., Allaf, K. (2010). Structure and attribute modifications of spray-dried skim milk powder treated by DIC (instant controlled pressure drop) technology. Dairy Science and Technology, 90(2-3), 301-320. DOI:10.1051/dst/2010008.

30. Reddy, R.S., Ramachandra, C., Hiregoudar, S., Nidoni, U., Ram, J. Kammar, M. (2014). Influence of processing conditions on functional and reconstitution properties of milk powder made from Osmanabadi goat milk by spray drying. Small Ruminant Research, 119(1-3), 130137. DOI:10.1016/j.smallrumres.2014.01.013.

31. Harper, V., Holsinger, K.K., Fox, M.J. (1963). Factors Influencing the Instant Solubility of Milk Powders. Journal of Dairy Science, 46(11), 1192-1195. DOI: 10.3168/jds.S0022-0302(63)89244-9

32. Strizhko, M.N., Semipyatnyi, V.K., Radaeva, I.A., Turovskaya, S.N., Karapetyan, V.V., Malova, T.I., Galstyan, A.G. (2014). To the items of efficiency of dry milk products reconsti-tution. Dairy Industry, 6, 6366. (in Russian)

33. Semipyatniy, V.K. (2014). Improvement of dry milk products recovery technology. The Author's Dissertation Abstract of the Candidat of Technical Science. Kemerovo: Kemerovo Technological Institute of Food Industry. - 18 p. (in Russian)
34. Semipyatnyi, V.K., Strizhko, M.N., Galstyan, A.G.(2013). Improvement of the process of milk powder solution: modeling of the system "many particles-liquid". Dairy Industry, 12, 36-37. (in Russian)

35. Galstyan, A.G., Petrov, A.N., Semipyatniy, V.K. (2016). Theoretical backgrounds for en-hancement of dry milk dissolution process: mathematical modeling of the system "solid particles - liquid". Food and Raw material, 4(1), 102-109. DOI:10.21179/2308-4057-2016-1102-109.

36. Van Knegsel, A.T.M., Remmelink, G.J., Jorjong, S., Fievez ,V., Kemp, B. (2014). Effect of dry period length and dietary energy source on energy balance, milk yield, and milk composition of dairy cows Journal of Dairy Science, 97(3), 1499-1512. DOI: 10.3168/jds.20137391

37. Baldwin, A. J. (2010). Insolubility of milk powder products - A minireview. Dairy Science and Technology, 90(2-3), 169-179. DOI:10.1051/dst/2009056.

38. Baldwin, A.J., Truong, G.N.T (2007). Development of insolubility in dehydration of dairy milk powders. Food and Bioproducts Processing 85(C3), 202-208. DOI: 10.1205/fbp07008

39. Anema, S.G., Pinder, D.N., Hunter, R.J., Hemar, Y. (2006). Effects of storage temperature on the solubility of milk protein concentrate (MPC85). Food Hydrocolloids, 20(2-3 SPEC. ISS.), 386-393. DOI: 10.1016/j.foodhyd.2005.03.015

40. Galstyan, A.G., Petrov, A.M., Chistovalov, N.S. (2007). The advanced water preparation technologies for reconstituted dairy products manufacture. Storage and processing of farm products, 11, 30-33. (in Russian)

41. El Moghazy, A.H. (2011). Nontraditional ways of water preparation for whey-based bev-erages production. Food Processing: Techniques and Technology, 4(23), 72-77. (in Russian)

42. Lipatov, N.N., Tarasov, K.I.(1985). Recovered milk (theory and practice of production of reconstituted dairy products). M, Agropromizdat. 256 p. (in Russian)

43. Galstyan, A.G., Petrov, A.N., Pavlova, V.V., Turovskaya, S.N., Stepanchenko, D.V. (2003). The effect of water on the recoverability of dry milk raw materials. In the collection: The development of the ideas of Academician Lipatov Nikolai Nikitovich at the turn of the century. Scientific and practical aspects of milk processing. Dedicated to the 80th birthday of academician Nikolai Nikitovich Lipatov. M, 44-49. (in Russian)

44. Pham, M.P.T., Castle, J.W., Rodgers, J.H. (2011). Application of water quality guidelines and water quantity calculations to decisions for beneficial use of treated water. Applied Water Science, 1(3-4), 85-101. DOI:10.1007/s13201-011-0012-3

45. Schuck, P., Briard, V., Méjean, S., Piot, M., Famelart, M., Maubois, J. (1999). Dehydration by Desorption and by Spray Drying of Dairy Proteins: Influence of the Mineral Environment. Drying Technology, 17(7-8), 1347-1357. DOI: 10.1080/07373939908917619

46. Schuck, P., Davenel, A., Mariette, F., Briard, V., Méjean, S., Piot, M. (2002). Rehydration of Casein Powders: Effects of Added Mineral Salts and Salt Addition Methods on Water Transfer. International Dairy Journal, 12(1), 51-57. DOI: 10.1016/S0958-6946(01)00090-5

47. Dvoretsky, G.B. (1971). Wetting dry milk products. Dairy Industry, 11 23-25. (in Rus-sian)

48. Shvyrev, V.F. (1984). Development of modes of dissolution of dry milk and apparatus for its implementation. The Author's Dissertation Abstract of the Doctor of Technical Science. Moscow, Moscow Institute of National Economy. G.V.Plekhanova - 20 p. (in Russian)

49. Popova, N.V. (2014). Treated water processing in the recovery technology of milk processing products as a quality factor. Bulletin of the South Ural State University. Series: Food and Biotechnology, 2(4) 27-35. (in Russian)

50. Galstyan, A.G., Frolov, G.A., Shklovets, A.N., Malova, T I. (2011). Water treatment in the dairy industry. Milk Processing, 3, 36-38. (in Russian)

51. Frolov, G.A., Galstyan, A.G., Petrov, A.N. (2008). Systems of waterpreparation in manufacture of the restored dairy products. Food Industry, 3, 42-43. (in Russian)

52. Song, L., Aryana, K.J. (2014). Reconstituted yogurt from yogurt cultured milk powder mix has better overall characteristics than reconstituted yogurt from commercial yogurt pow-der. Journal of Dairy Science, 97(10), 6007-6015. DOI: 10.3168/jds.2014-8181.

53. Van Lent, K., Le, C.T., Vanlerberghe, B., Van der Meeren, P. (2008) Effect of Formulation on the Emulsion and Whipping Properties of Recombined Dairy Cream. International Dairy Journal, 18(10-11), 1003-1010. DOI:10.1016/j.idairyj.2008.04.002.

54. Popova, N.V. (2013). Innovations in milk powder recovery technology as a factor of quality management for reduced products of milk processing. Bulletin of the South Ural State University. Series: Economics and Management, 7(4), 181-186. (in Russian)

55. Galstyan, A.G., Petrov, A.N. (2008). About sorption isotherm of humidity of dry milk products. Storage and processing of farm products, 6, 32-35. (in Russian)

56. Aneja, R.P. (1988). Equipment for recombination. In: Recombination of Milk and Milk Products, Alexandria, Egypt, 12-16 November Special Issue 9001, Int. Dairy Fed., Brussels, Belgium, 186-195.

57. Anema, S.G., Li, Y. (2003). Re-equilibration of the minerals in skim milk during reconsti-tution. Milchwissenschaft, 58(3-4), 174-178.

58. Jeantet, R., Schuck, P., Six, T., Andre, C., Delaplace, G. (2010). The influence of stirring speed, temperature and solid concentration on the rehydration time of micellar casein powder. Dairy Science and Technology, 90(2-3), 225-236. DOI:10.1051/ dst/2009043 
59. Kudo, N., Hols, G., Van Mil, P.J.J.M. (1990). The insolubility index of moist skim milk powder: influence of the temperature of the secondary drying air. Neth. Milk Dairy J, 44, 89-98.

60. American Dry Milk Institute, Determination of solubility index. (1971). In: Bulletin 916 (Revised), Standards for Grades of Dry Milks Including Methods of Analysis, American Dry Milk Institute Inc., Chicago, Illinois, USA, 26-27.

61. Dried milk and dried milk products. Determination of insolubility index. (2005). IDF Standard 129. Int. Dairy Fed., Brussels, Belgium.

62. Dried milk and dried milk products. In determination of insolubility index. (1988). IDF Standard 129A. Int. Dairy Fed., Brussels, Belgium.

63. Popova, N.V., Potoroko, I.Yu.(2014). Quality and storability provision for rehydrated products of milk processing. Bulletin of the South Ural State University. Series: Food and Biotechnology, 2(3), 37-46. (in Russian)

64. Semipyatniy, V., Galstyan, A., Ryabova, A., Kharitonov, V., Stryzhko, M. (2014). Development of a scientific basis for powdered milk dissolution. Bulletin of the International Dairy Federation, 41-48.

65. Semipyatniy, V. K., Galstyan, A. G., Stryzhko, M. N. (2013). The program for calculating the heat balance of the recovery process of dry milk: Certificate of official registration of the computer program No. 2014611919. Moscow: Rospatent. (in Russian)

66. Semipyatniy, V. K., Galstyan, A. G. (2014). The program for calculating the amount of energy used in the process of restoring dry milk: Certificate of official registration of the computer program No. 2014614795. Moscow: Rospatent. (in Russian)

67. Semipyatniy, V. K., Galstyan, A. G., Radaeva, I.A., Pryanishnikova, N.S (2017). The program for calculating the rate of ascent of particles in solutions with variable environmental parameters: Certificate of official registration of the computer program No. 2017662376. Moscow: Rospatent. (in Russian)

68. Semipyatniy,V.K.,Galstyan,A.G., Turovskaya,S.N.,Pryanishnikova, N.S. (2017). The program for determining the flow regimes in the particleliquid system in the absence of external influence: Certificate of official registration of the computer program No. 2017662377. Moscow: Rospatent. (in Russian)

69. Galstyan, A. G., Semipyatniy, V. K., Illarionova, E.E., Belyakova, Z.Yu. (2017). The program for calculating the time of settling of particles in solutions with variable parameters of the medium: Certificate of official registration of the computer program No. 2017662378 Moscow: Rospatent. (in Russian)

70. World Health Organization website [Electronic resource: https:// www.who.int/ru Access date 01.02.2019]

71. European Parliament website [Electronic resource: http://www. europarl.europa.eu/portal/en Access date 01.02.2019

72. Rakhmanin, Ju. A., Krasovsky, G. N., Egorova, N. A., Mikhailova, R. I. (2014). 100 years of drinking water regulation. retrospective review, current situation and prospects . Hygiene and Sanitation, 2, 5-18. (in Russian)

73. Galstyan,A.G. (2005). Practical aspects of water treatment to improve the dissolution of dry dairy products. Storage and processing of farm products, 2, 22-23. (in Russian)

74. Krasnova, T.A. (2018). Water treatment in food industry. Food Processing: Techniques and Technology, 48(1), 15-30. (in Russian)

75. Korotkaya, E.V., Korotkiy, I.A. Uchaykin A.V. (2018). Water Purification by Separate Freezing in Reconstituted Milk Production. Food Processing: Techniques and Technology, 48(3), 133-139. DOI: 10.21603/2074-9414-2018-3-133-139 (in Russian)

76. Galstyan, A.G., Chervetsov, V.V., Turovskaya, S.N., Shklovets, A.N (2011). Preparation of water is a factor for improving economical efficiency of enterprise. Dairy Industry, 2, 58-60. (in Russian)

77. Galstyan, A.G., Petrov, A.N. (2006). Nontraditional ways of preparing water for powder products solving. Dairy Industry, 10, 66-67. (in Russian)

78. Ryabchikov, B.E. (2013). Modern water treatment. M, DeLi plus. - 680 p. ISBN 978-5-905170-49-2. (in Russian)

79. Shestakov, S.D., Krasulya, O.N., Rink, R., Ashokkumar, M. (2013). Ultrasonic treatment of dairy systems to improve their properties. Technical acoustics, 7, 1-9. (in Russian)

80. Popova, N.V. (2014). Ensuring the quality of the recovered milk processing products and the intensification of their production based on ultrasound exposure.The Author's Dissertation Abstract of the Candidate of Technical Science. Kemerovo: Kemerovo Technological Institute of Food Industry. - 18 p. (in Russian)

\section{AUTHOR INFORMATION}

Svetlana N. Turovskaya - Researcher, Laboratory of dairy canned products, All-Russian Research Institute of Dairy Industry, 115093, Moscow, Lyusinovskaya Str., 35, Tel.: +7-499-236-02-36, E-mail: conservlab@mail.ru. * corresponding author

Andrey N. Petrov - Doctor of Technical Science, Academician of RAS, Director, All-Russian Scientific Research Institute of Technology of Preservation Branch of the V.M. Gorbatov Federal Research Center for Food Systems of RAS 142703, Moscow region, Vidnoe, School Str., 78, Tel.: +7(495)549-88-00, E-mail: vniitekpetrov@vniitek.ru

Iskra A. Radaeva - Doctor of Technical Science, Professor, Chief Researcher, Laboratory of dairy canned products, All-Russian Research Institute of Dairy Industry, 115093, Moscow, Lyusinovskaya Str., 35 , Tel.: +7-499-236-02-36,E-mail: conservlab@mail.ru

Elena E. Illarionova - Researcher, Laboratory of dairy canned products, All-Russian Research Institute of Dairy Industry, 115093, Moscow, Lyusinovskaya Str., 35, Tel.: +7-499-236-02-36, E-mail: conservlab@mail.ru

Vladislav K. Semipyatniy - Candidate of Technical Science, Researcher of the Interbranch Scientific and Technical Center for Food Quality Monitoring, All-Russian Scientific Research Institute of the Brewing, Non-Alcoholic and Wine Industry - Branch of the V.M. Gorbatov Federal Research Center for Food Systems of RAS, 119021, Moscow, Rossolimo Str., 7, Tel.: +7-499-245-61-18, E-mail: mntc.monitoring@gmail.com

Anastasia E. Ryabova - Candidate of Technical Science, Researcher of the Interbranch Scientific and Technical Center for Food Quality Monitoring, All-Russian Scientific Research Institute of the Brewing, Non-Alcoholic and Wine Industry - Branch of the V.M. Gorbatov Federal Research Center for Food Systems of RAS, 119021, Moscow, Rossolimo Str., 7, Tel.: +7-499-245-61-18, E-mail: mntc.monitoring@gmail.com Authors are equally relevant to the writing of the manuscript, and equally responsible for plagiarism

The authors declare no conflict of interest

Received 10.01.2019 Accepted in revised 11.03.2019 Accepted for publication 22.03.2019 